Brit. F. vener. Dis. (1969), 45, 58.

\title{
THE FIRST VENEREOLOGISTS*
}

\author{
BY
}

\author{
R. S. ROBERTS \\ Department of History, University College, Salisbury, Rhodesia
}

Whatever is the true history of syphilis ${ }^{1}$, there can be little doubt that it was in the late 15th and early 16 th centuries that the disease first became a matter of wide concern. Its impact on medicine was immediate. Only then did public hospitals begin to assume their modern curative functions and cease to be mere places of refuge for sick, needy, and old alike $^{2}$. The treatment of the disease quickly fell into the hands of surgeons rather than physicians, for it was regarded as a skin complaint and so treated with mercury which had long been used for such eruptions. In this way there evolved the first specific in the cure of disease.

Physicians, however, claimed that they could, and should, cure the disease and, because of its supposed exotic origin in the West Indies, they tended to look to the New World for a cure on the ground that God in his mercy always provided a remedy locally. Thus it was that guaiacum, seen in St. Domingo by Oviedo in 1514, was soon imported into Europe; and bankers, like the Fuggers, and medical men like L'Escluse and Monardes, co-operated in what was almost an advertising campaign ${ }^{3}$. This extended to England in 1533, when Thomas Paynell translated a work by von Hutten to popularize guaiacum on behalf of the importers, who "feared, leest they shulde selle but lytel, if the phisitiins allowed it not ... [ [for] no man woldee lyghtly go unto a medicine, that came from so strange a place. .."4.

For several reasons the physicians failed to monopolize the treatment of syphilis; the virulence of the disease, the large numbers affected, the desire for secrecy in treatment, and the dispute over remedies, all encouraged men, some not even medically trained, to set up as specialists in venereal disease; indeed some of them, for the purposes of better treatment and privacy, instituted the first private nursing homes ${ }^{5}$.

^Received for publication, March 28, 1968

Address for reprints: P.B. 167H, Salisbury, Rhodesia.
The first such specialist in English history was one Richard Alison, described as a tailor and otherwise unknown. He drew attention to himself in London in June, 1516, by acting as commoninformer against three barbers, whom he accused of practising surgery without the licence of the Bishop of London as required by the medical licensing Act of $1512^{6}$. The fact that all three barbers were immediately able to produce valid licences may indicate that Alison was merely pursuing a personal vendetta against rivals in practice? If so, retribution was not long in coming, for in February, 1517, a licensed Barber-Surgeon, who also made a habit of prosecuting his medical rivals, accused Alison of unlicensed practice of physic and surgery and sued him for a fine of $£ 15$. Alison, in his defence, admitted treating several husbands and their wives in the Holborn area of London, but denied that in so doing he had broken the law regarding the practice of physic or surgery:

For he was learned in confections and medicines for the treatment of certain diseases called "pokkes or the great pokkes" the cure of which pertained neither to the faculty of physic nor to the faculty of surgery ${ }^{8}$.

It seems that no ruling was ever given on this defence as the case peters out in the record. The implication for medical practice nevertheless was clear: venereology was a new skill in respect of a new disease and therefore was not to be restricted by the existing rules of medicine and surgery. In Alison's case this no doubt was special pleading but the later history of the treatment of syphilis was to show that there was much truth in it.

Alison's argument in fact made clear to the physicians the inadequacies of the Act of 1512 which had been designed to perpetuate the traditional separation of the practice of physic from that of surgery; and it was partly for this reason that the physicians obtained a charter in 1518 to establish the Royal College of Physicians. There- 
after one of the main tasks of this august body was the disciplining of surgeons and other humble practitioners who treated venereal disease with internal as well as external medicaments. So strongly did the physicians try to enforce their monopoly of physic that in 1572 there was held a public inquiry in which the Bishop of London defended the surgeons' use of internal medicines as being in the public interest. The decision nevertheless went against the surgeons ${ }^{9}$ and the College of Physicians thereafter unrelentingly pursued nonmembers who presumed to prescribe decoctions, purges, sudorifics, pills, or even $\operatorname{diet}^{10}$.

Such a policy of restriction and repression could not succeed. There simply were not sufficient physicians to meet the demand and surgeons who treated venereal disease could not be confined to the employment of mercury alone. Both they and their patients had been made aware of the advertised wonders of guaiacum, sarsaparilla, and china roots, and they were determined to make sure of the mercury-treatment by uising decoctions of these exotic plants ${ }^{11}$. The extent to which they did so can be gauged from the fact that virtually the whole of the import of drugs into England in the late 16th century was of these three remedies for syphilis ${ }^{12}$. It was indeed fortunate that, amidst this plethora of useless exotics, the knowledge of the specific value of mercury was not lost from view, as did happen in the case of scurvy and its treatment by the juice of citrus fruits; had syphilis been left to physicians and their irrepressible tendency to theorization this might well have happened.

The surgeons luckily had a more empirical approach to medical problems, but it must not be thought by this that the surgeons were uneducated. Their leaders not infrequently published books and pamphlets to demonstrate the surgeons' knowledge and skill in treating venereal disease ${ }^{13}$. One such interesting work alluded to experiments that had been performed on dogs to test whether mercury was harmful when taken internally ${ }^{14}$. It is obvious that there was plenty of scope for these surgeons: one of their publications maintained that half of all patients admitted into St. Bartholomew's Hospital were suffering from venereal disease ${ }^{15}$.

The claims made on behalf of surgeons did not remain limited to a demand to use internal medicines in cases of venereal disease only. The confidence gained in using remedies like guaiacum soon encouraged surgeons to use internal medicines in the treatment of other conditions, especially those such as rickets which physicians tended to neglect. Thus in effect the surgeon was overthrowing the traditionally rigid differentiation between physic and surgery, and setting himself up as a general practitioner. Such a development was naturally opposed by the monopolistic College, but in failing to respond to the new medical needs of a growing population, the physicians nevertheless effectively left the way open for the freedom of medical practice by the early 18 th century. In this way many surgeons did become general practitioners and so became known as apothecary-surgeons or surgeon-apothecaries. Of those who remained with the description of surgeon, only a few like Cheselden were actually performing surgery. The majority still tended to treat skin complaints, dress ulcers, and the like; indeed it was "the Cure of Venereal Disease, upon which alone the Subsistance of three Parts in four of ail Surgeons in Town" depended ${ }^{\mathbf{1 6}}$. Thus later in the 18th century, when Boswell ${ }^{17}$ and Hickey $^{18}$ found that their dalliance in Covent Garden made medical treatment necessary, they called in local surgeons, $\mathrm{Mr}$ Douglas and $\mathbf{M r}$ Hayes respectively; Keats similarly in 1818 did not call in a doctor but Mr Solomon Sawrey who specialized in venereal diseases ${ }^{19}$.

In conclusion, it is of some interest to inquire whether the history of the treatment of venereal disease, so briefly outlined, has in any way affected the development of modern venereology. It is sometimes claimed that venereology does not receive its due recognition from the public, and even from other sections of the medical profession; and one wonders whether this is not so much the residual effect of Victorian prudery, as often suggested, but rather the result of the strong social differentiation in the 18th and 19th centuries between the mere "surgeons" who treated venereal disease and the rest of the medical profession.

This suggestion that historical associations, with social implications, have affected the public esteem of a modern branch of medicine may appear farfetched, but it is as well to remember that such an association, albeit in a debased form, has remained strongly in the public mind in respect of shops of a certain type which originally sprang into existence in the Charing Cross area where the Boswells and Hickeys roamed. In their windows, till to-day, the appliances and lotions of erstwhile surgeons, for the treatment of rupture, swollen ankles, and dandruff, vie incongruously with the needs of venery; and it was only the exigencies of the Great War ${ }^{20}$ that finally removed the potions and unguents devised by 18th century surgeons for the cure of venereal disease from public display alongside the surgeons' trusses. 


\section{BIBLIOGRAPHY}

1. For a discussion of this, see HACKETt, C. J., "On the origin of the human treponematoses ....", Bull. Wld Hlth Org. (1963), 29, 7-41; CockBURN, A., "The Evolution and Eradication of Infectious Diseases" (1963), pp. 152-174. Johns Hopkins Press, Baltimore; Hudson, G. H., "Treponematoses and African slavery", Brit. $\mathcal{F}$. vener. Dis. (1964), 40, 43-52; MORTON, R. S., "Another look at the Morbus Gallicus", Brit. F. vener. Dis. (1968), 44, 174.

2. SUDHOFF, K., "Ein Wendpunkt im Spitalwesen des Mittelalters im Abendlande", 85. Versammlung Deutscher Naturforscher und Aertz, Münch. med. Wschr. (1913), 60, 2482-2483.

3. See, for example, three works written between 1517 and 1519:

Pols, N., "De cura morbi gallici per lignum guaycanum" (1535), G. Paduano, and V. Ruffinelli, Venice.

SchmaUs, L., "De morbo gallico tractatvs" (1518), Salzburg.

HutTeN, U. voN, "De guaiaci madicina . . ." (1519), J. Scheffer, Mainz.

These and many other early tracts on syphilis were brought together by Aloysius Lusinus [Luigi Luisini] and published in various editions, notably, "De morbo gallico omnia qvae extant ..." (1566-7), 2 pts. in 1 vol., J. Zilettus, Venice; "Aphrodisiacus ..." (1728), 2 pts. in 1 vol., J. A. Langerak and J. and H. Verseek, Leiden (with an additional volume by C. G. Gruner (1789), heirs of C. H. Cuno, Jena).

4. Hutten, U. von, "De morbo gallico" (1533), trans. T. Paynel, f.2A [sic.], T. Berthelet, London.

5. See, for example, the author turned physician, LODGE, THOMAs, Historical Manuscripts Commission, Report, Salisbury, XI, pp. 356-7. See also the many references in plays of the period in M. YeARSLEY, "Doctors in Elizabethan Drama" (1933), p. 63. Bale, Sons and Danielsson, London.

6. Statutes of the Realm, 3, Henry VIII, c.11. For the operation of this system, see ROBERTS, R. S., "The Personnel and Practice of Medicine in Tudor and Stuart England", Med. Hist. (1962), 6, 363-382; (1964), 8, 217-234.
7. $\mathrm{P}$ [ublic] R[ecord] O[ffice], Exchequer, King's Remembrancer, Memoranda Rolls, 8 Henry VIII, Michaelmas, mm. 18, 22, $22^{d}$.

8. Ibid., Hilary, m. 21-d.

9. Clark, Sir George, "A History of the Royal College of Physicians of London" (2 vols, 19641966), vol. 1, p. 121. Clarendon Press, Oxford.

10. See for example the prosecutions and warnings, Royal College of Physicians, "Annals, 1581-1608", f. $88(1590)$, ff. 117,118 (1595), f. $144^{\mathrm{d}}(1600)$, f. $156^{\mathrm{d}}(1602)$, ff. $169,171^{\mathrm{d}}, 172$ (1603), and ff. $183,196^{\mathrm{d}}(1605)$.

11. For the use of these drugs, see Flückiger, F. A., and HANBURY, D., "Pharmacographia ..." (2nd ed., 1879), pp. 101, 706, 712. Macmillan, London.

12. P.R.O. Exchequer, Queen's Remembrancer, Port Books $4 / 2,7 / 8$ and $8 / 1$. This aspect has been discussed in more detail, in ROBERTS, R. S., "The Early History of the Import of Drugs into Britain", printed in "The Evolution of Pharmacy in Britain" (1955), ed. F. N. L. Poynter, pp. 165-185. Pitman Medical Publishing Co., London.

13. See, for example, ClowEs, W., "A Short and Profitable Treatise touching the Cure of the Disease called Morbus Gallicus by Unctions" (1579), especially, sig. Av. I. Daye, London; and BAKER, G., "The Composition or Making of the moste excellent and pretious oil called Oleum Magistrale . . ." (1574 [1575]), ff. 37-40d. J. Alde, London.

14. BAKER, G., "The Nature and Propertye of Quicksilver ...", printed in Clowes, op. cit., sig. Eviii-d

15. Clowes, op. cit., sig. Aid-Aii.

16. CAMPBELL, R. “The London Tradesman ..."(1747), p. 52. T. Gardner, London.

17. "Boswell's London Journal 1762-1763" (1950), ed. F. A. Pottle, pp. 155-158, 173. Heinemann, London; "Boswell: the ominous years 1774-1776" (1953), ed. C. Ryskamp, and F. A. Pottle, pp. 326-327, 332, 339. Heinemann, London.

18. "Memoirs of William Hickey" (1960), ed. P. Quennell, p. 171. Hutchinson, London.

19. WARD, A., "John Keats" (1963), p. 134. Secker and Warburg, London.

20. Venereal Diseases Act, 1917, 7 and 8, George V, c. 21 . 